\title{
FACTORS AFFECTING SCHOOL PERFORMANCE: DOES A MIXED CURRICULUM MAKE A DIFFERENCE?
}

\author{
Stefy Falentino Akuba *, Poltak Sinaga, Gracia Shinta S Ugut, Sidik Budiono \\ Universitas Pelita Harapan, Tangerang, Indonesia \\ *e-mail: stefyakuba@gmail.com
}

\begin{abstract}
This article reports on a study that attempts to fill the gap of research focusing on school performance measurements, especially those which involve curriculum types. It established the factors that measured school performance using Exploratory Factor Analysis (EFA) and Confirmatory Factor Analysis (CFA) and analyzed any differences in the performance of schools adopting national curriculum and those adopting mixed curriculum in Greater Jakarta. From 29 items, eight invalid items were dropped, and the EFA identified eight factors, which were categorized into social-emotional learning, school participation, relationship, physical-mental health, physical safety, emotional safety, academic growth, and discipline. Then, the scale was validated using data collected from 684 secondary students using CFA. Chi-square goodness-of-fit test was not statistically significant. However, other indices such as Incremental Fit Index, Comparative Fit Index, Tucker-Lewis Index, Root Mean Squared Error of Approximation, and Standardized Root Mean Square Residual were within acceptable limits, indicating that the eight EFA factors had been validated. Moreover, this study found that schools with mixed curricula had higher performance than those with a national curriculum. Nevertheless, it cannot be generalized because the linear regression shows that the $p$-value was higher than $0.05(0.164)$.
\end{abstract}

Keywords: school performance, national curriculum, mixed curriculum, confirmatory factor analysis

\section{FAKTOR-FAKTOR KINERJA SEKOLAH: APAKAH KURIKULUM CAMPURAN MEMBUAT PERBEDAAN?}

\begin{abstract}
Abstrak: Penelitian ini dilakukan karena kurangnya pengukuran kinerja sekolah terutama yang melibatkan tipe kurikulum. Studi ini menentukan faktor-faktor yang membangun model instrument untuk mengukur kinerja sekolah dengan menggunakan Exploratory Factor Analysis (EFA), Confirmatory Factor Analysis (CFA) serta untuk melihat adakah perbedaan yang berhubungan dengan kinerja sekolah antara sekolah berkurikulum nasional dengan sekolah berkurikulum campuran di Jakarta dan sekitarnya. Dari 29 butir, setelah delapan butir dibuang karena tidak valid, dikategorikan oleh EFA menjadi delapan faktor yang kemudian dilabeli pembelajaran sosial emosional, partisipasi, hubungan, kesehatan fisik-mental, keamanan fisik, keamaan emosional, pertumbuhan akademis dan disiplin. Model yang terbentuk divalidasi dengan CFA menggunakan data yang 684 murid menengah pertama dan atas. Hasil menunjukkan chi-square goodness of fit statistics didapati tidak signifikan, tetapi indikator lain seperti Incremental Fit Index, Comparative Fit Index, Tucker-Lewis Index, Root Mean Squared Error of Approximation dan Standardized Root Mean Square Residual memberikan hasil yang dapat diterima sehingga delapan faktor dari EFA tervalidasi. Dari hasil kuesioner yang diisi didapati bahwa kinerja sekolah dengan kurikulum campuran lebih tinggi dibanding sekolah dengan kurikulum nasional, tetapi hal tersebut tidak dapat digeneralisasi karena hasil dari regresi linier menunjukkan nilai $p$ lebih tinggi dari 0,05 (0.164).
\end{abstract}

Kata Kunci: kinerja sekolah, kurikulum nasional, kurikulum campuran, confirmatory factor analysis

\section{INTRODUCTION}

The curriculum quality has an essential part in the academic achievement of students (Andrietti \& Su, 2019; Dewi, 2021; Krupa \& Confrey, 2017). Therefore, the curriculum, a series of lesson plans and subjects of learning materials, which are implemented at school should be able to address and improve students' learning outcomes. Still, it can be used as the guideline for policymakers and society to set some agreement regarding education which can answer the future needs in ontology, epistemology, and axiology (Tedesco et al., 2014). Thus, the curriculum becomes a policy representative 
in the education system that is presented in a class.

Policymakers in Indonesia also continue to develop their national curriculum. The curriculum in Indonesia can be categorized based on dynamic, contextual, and relative policy products (Andrian et al., 2018). In the latest development, Indonesia uses a national curriculum known as Curriculum 2013. The curriculum is considered to emphasize modern learning by using an evidence-based approach. The thematic learning process in the Curriculum 2013, according to the Ministry of Education and Culture (2014), purposely uses a scientific approach to provide a space for students to master learning materials by not just relying on teachers alone. Students are educated to become long-life learners. Therefore, the learning process must be based on three main factors namely, skills, attitude, and knowledge.

In addition to the national curriculum, the government also allows private schools to use international curricula such as Cambridge International, International Baccalaureate, and others. Initially, the government allows these schools to use the name International school until finally the government issued the Regulation of the Minister of Education and Culture No. 31 of 2014. Since the publication of this regulation, schools in Indonesia no longer use international labels but changed their status to SPK - Satuan Pendidikan Kerjasama (Joint Education Unit).

Parents in urban areas are interested in sending their children to SPK schools (Rinaldi \& Saroh, 2017), mostly because their children desire to master a foreign language early on. The increasing use of English as a communication medium in Indonesia is in line with the increasing number of SPK schools. In non-anglophone countries, there tends to be a rapid change from English as a foreign language (EFL) to English as the medium of instruction (EMI) for academic subjects such as science, mathematics, geography, and medicine (Dearden, 2016). Many families in non-English-speaking countries consider learning English from an early age to be a critical factor in achieving global higher education success, international job opportunities, and prosperity (Muslim et al., 2020; Santos, 2019). Policymakers, educators, and business organizations in some countries regard English-medium teaching as a "golden ticket to a global world" (Galloway et al., 2017; Shimauchi, 2018; Zhang, 2018).
In the research on why parents particularly preferred an international school, around 83 percent of school admission staffs agreed that the curriculum seemed to be "very significant" to most parents, while 17 percent believed that it is 'somewhat relevant,' and none of them were sure whether parents were concerned about the curriculum (ISC Research, 2021). Today's SPK schools are more likely to adopt an international curriculum or provide an adapted version of a national curriculum that pay attention to what country a school belongs. Mixed curriculum models are also developing, incorporating various national as well as international curricula strands, including the host country's national curriculum elements (Buchanan et al., 2018; Hameed, 2020; Sihotang \& Datrix, 2018). Today, many international schools use a flexible curriculum tailored to meet the needs of the school's venue, student population, and strengths. However, does the mixed curriculum make schools perform better than schools that use the national curriculum? This question then became a reference for this study.

The average standardized test results have many limitations to measure school performance but are still often used (López, 2019; Schneider et al., 2017). Generally, in the search for the schools with good performance in Jakarta, we will be given a list of schools with the highest average in the entrance test of public universities or other standardized test results. Meanwhile, parents and people of the community tend to focus on other indications of school excellence. They mostly rely on reputation, word-of-mouth, and what they see with their own eyes, such as facility facilities or student demographics (Mayer et al., 2020; Schneider et al., 2017).

Shreds of evidence show that a wide variety of academic and life outcomes are predicted by non-cognitive skills or student skills other than academic achievement (Duckworth \& Yeager, 2015; West, 2016). These non-cognitive attributes are varied, but they all work together to support the goal-directed effort, for example, social-emotional skill (Brackett, 2016; Durlak et al., 2011; Goldberg et al., 2019) and emotional intelligence (Astatke, 2019; Molla, 2018; Rai \& Khanal, 2017). Besides, longitudinal studies have shown that these characteristics are significant predictors of academic, economic, social, psychological, and physical wellbeing (Duckworth \& Yeager, 2015; Jackson et al., 2015). 
In public education, the value of reliably evaluating academic success is critical. To ensure all students get high-quality education, schools must provide acceptable academic proficiency and advancement metrics. However, considering school performance, concentrating solely on the standards-based academic testing may lead to misrepresentation of student/school performance, streamlining of course work around restricted subjects, and an overemphasis on student outcomes over the multitude of personal, contextual, and environmental factors contributing to student's academic knowledge, wellbeing, and individual development (Babineau, 2017; Saputra et al., 2020).

This study examined the impact of school form on academic proficiency, school climate, and social/emotional learning (SEL) rather than academic achievement. This paper was based on the data obtained from Greater Jakarta secondary students in grade 7-12. The performance of mixed curriculum schools (SPK schools) and national schools were compared based on students' perceptions. The aim of this study was to establish the factors that measured school performance using Exploratory Factor Analysis (EFA) and Confirmatory Factor Analysis (CFA). In addition to establishing the factors, this study, by using linear regression, was also aimed at observing whether any school-related performance could give some benefits to students who considered national and mixed curriculum schools.

\section{METHODS}

This study used a quantitative method by using questionnaires to measure students' perception of schools' performance in Greater Jakarta. This study employed school performance as a latent variable consisting of some indicators as the sub-constructs, such as academic proficiency, school climate, facilities, safety, and social/ emotional learning. The sampling techniques applied were purposive sampling and snowball sampling using an individual unit analysis. Six hundred eighty-four secondary students from 132 public and private schools in Greater Jakarta officially participated as research respondents. The description of the participants can be seen in Table 1 .

The questionnaire was given to secondary students, and the results were gathered. Then, a confirmatory factor analysis with Lisrel was used to look at the contribution of each aspect as mentioned above to overall school performance. In addition, SPSS was used to see a different performance between national curriculum schools and mixed curriculum schools with simple linear regression. The following steps were used to collect the data. First, students were given a set of questions asking about their school performance. The questionnaire was uploaded to Google Form, so the results could be easily drawn right after the link was spread out. Next, the students answered the questionnaire independently at their own places, without any distraction from other parties, such as school staffs or researchers. The designed measurement was divided into two different parts: (1) a set of questions about the profile of participants (gender, degree of study, school's location, and school's curriculum); (2) a set of questions about the school performance. The answer type was ranged from 1 to 5 on a 5-point Likert scale, with 1 indicating strong disagreement and 5 indicating strong agreement. For the factor analysis, Mundfrom et al. (2005) suggested a minimum sample size of $t$ to 20 observations per scale item or 100 to over 1000 participants.

The designed instrument was initially given to 30 students as the part of the pilot study. The pre-test allowed researchers to see if various response groups accurately phrased, arranged, and understood the questions. Before the full-scale study, some errors found during the implementation were fixed. The content validity of the research instrument was confirmed by confirming the study's goal aligned with the items in the research instruments, and the items were assessed by three experts in education prior to the implementation of data collection. Cronbach's alpha of 29 items' reliability ranging from 0.772 to 0.792 , indicating that the instrument was reliable, as shown in Table 2. For Exploratory Factor Analysis (EFA), SPSS Version 25 was used, while Lisrel was employed for Confirmatory Factor Analysis (CFA). The first stage was to determine the standard normal distribution by ensuring that the kurtosis $(<7)$ and skewness $(<2)$ were within acceptable limits (George \& Mallery, 2010). Next, the mean, standard deviation, skewness, and kurtosis were used to assess twenty-nine variables (Table 2) the mean with a range of 3.25 to 4.01 and a standard deviation of 0.825 to 1.373 . The skewness was between -0.879 and -0.084 , while the kurtosis was between -1.207 and 0.037 . 
Table 1. Research Respondent

\begin{tabular}{|c|c|c|c|c|}
\hline & \multirow{2}{*}{ Criteria } & \multicolumn{2}{|c|}{ Schools } & \multirow{2}{*}{ Total } \\
\hline & & National Curriculum & Mixed-Curriculum & \\
\hline \multicolumn{5}{|l|}{ Grade } \\
\hline & Grade 7 & 60 & 24 & 84 \\
\hline & Grade 8 & 34 & 144 & 178 \\
\hline & Grade 9 & 60 & 84 & 144 \\
\hline & Grade 10 & 34 & 46 & 80 \\
\hline & Grade 11 & 72 & 18 & 90 \\
\hline & Grade 12 & 92 & 16 & 108 \\
\hline & & \multicolumn{3}{|c|}{ Total $=$} \\
\hline \multicolumn{5}{|l|}{ Gender } \\
\hline & Female & 166 & 194 & 360 \\
\hline & Male & 186 & 138 & 324 \\
\hline & & \multicolumn{3}{|c|}{ Total $=$} \\
\hline \multicolumn{5}{|l|}{ District } \\
\hline & Jakarta Barat & 60 & 124 & 184 \\
\hline & Jakarta Pusat & 64 & 26 & 90 \\
\hline & Jakarta Selatan & 59 & 41 & 100 \\
\hline & Jakarta Timur & 44 & 10 & 54 \\
\hline & Jakarta Utara & 72 & 74 & 146 \\
\hline & Bekasi & 18 & 14 & 32 \\
\hline & Bogor & 4 & 12 & 16 \\
\hline & Depok & 12 & 2 & 14 \\
\hline & Tangerang & 19 & 29 & 48 \\
\hline & & \multicolumn{3}{|c|}{ Total $=$} \\
\hline
\end{tabular}

Table 2. Descriptive Statistics $(n=684)$

\begin{tabular}{|c|c|c|c|c|c|}
\hline Item's Codes & Mean & Std. Deviation & Skewness & Kurtosis & Cronbach's Alpha \\
\hline SEL1 & 3.58 & 0.997 & -0.112 & -0.822 & 0.779 \\
\hline SEL2 & 3.75 & 0.954 & -0.277 & -0.696 & 0.779 \\
\hline SEL3 & 3.25 & 1.200 & -0.272 & -0.758 & 0.772 \\
\hline SEL4 & 3.48 & 1.201 & -0.467 & -0.596 & 0.774 \\
\hline SEL5 & 3.46 & 1.173 & -0.492 & -0.455 & 0.778 \\
\hline SEL6 & 3.48 & 1.169 & -0.536 & -0.405 & 0.772 \\
\hline SPA1 & 3.82 & 0.944 & -0.450 & -0.226 & 0.781 \\
\hline SPA2 & 3.83 & 0.972 & -0.526 & -0.108 & 0.784 \\
\hline SPA3 & 3.51 & 1.294 & -0.534 & -0.826 & 0.792 \\
\hline SPA4 & 3.57 & 1.223 & -0.610 & -0.496 & 0.781 \\
\hline SPA5 & 3.79 & 1.169 & -0.879 & 0.037 & 0.780 \\
\hline REL1 & 3.97 & 0.885 & -0.558 & -0.068 & 0.786 \\
\hline REL2 & 3.83 & 0.931 & -0.390 & -0.476 & 0.777 \\
\hline REL3 & 3.77 & 0.920 & -0.270 & -0.480 & 0.779 \\
\hline PMH1 & 3.73 & 0.926 & -0.330 & -0.132 & 0.784 \\
\hline PMH2 & 3.94 & 0.943 & -0.634 & 0.086 & 0.785 \\
\hline РMH3 & 3.66 & 0.975 & -0.267 & -0.513 & 0.778 \\
\hline PSA1 & 3.79 & 0.860 & -0.084 & -0.639 & 0.785 \\
\hline PSA2 & 3.66 & 1.109 & -0.536 & -0.334 & 0.781 \\
\hline PSA3 & 3.97 & 0.850 & -0.360 & -0.619 & 0.779 \\
\hline ACG1 & 3.97 & 0.870 & -0.256 & -1.007 & 0.783 \\
\hline ACG2 & 3.89 & 0.858 & -0.281 & -0.439 & 0.780 \\
\hline ACG3 & 4.01 & 0.877 & -0.498 & -0.214 & 0.785 \\
\hline ESA1 & 3.73 & 0.985 & -0.451 & -0.184 & 0.782 \\
\hline ESA2 & 3.08 & 1.373 & -0.117 & -1.207 & 0.787 \\
\hline ESA3 & 3.72 & 1.015 & -0.325 & -0.655 & 0.778 \\
\hline DIS1 & 4.00 & 0.825 & -0.306 & -0.620 & 0.782 \\
\hline DIS2 & 3.84 & 0.970 & -0.539 & 0.036 & 0.778 \\
\hline DIS3 & 3.87 & 0.896 & -0.185 & -0.975 & 0.776 \\
\hline
\end{tabular}


The Kaiser-Meyer-Olkin (KMO) Measure of Sampling Adequacy (> 0.5) and Bartlett's Test of Sphericity $(<0.05)$ were used to filter data in the initial factor analysis (EFA) phase (Williams et al., 2010). A parallel analysis using Principal Component Analysis was done to determine the number of factors kept in the model (Iantovics et al., 2019; Ledesma \& Valero-Mora, 2007). There were 29 items calculated with a sample size of 684, and factors with Eigenvalues $>1$ were evaluated (Hayton et al., 2004). According to Hayton et al. (2004), eight factors that gave the researchers the confidence to proceed to the EFA were identified, categorized as social-emotional learning, school participation, relationship, physical mental health, physical safety, emotional safety, academic growth, and discipline.

The CFA was done to validate the identified factors, and a variety of indices were used to determine the model's fit. However, Jöreskog et al. (2016) said choosing fit indices indicating the best fit is critical, and providing everything in the program output would be too much for the reader, so, in this study, the model was evaluated using the Chi-square goodness of fit statistics (p>0.05), the Comparative Fit Index (good fit: CFI $>0.97$; mediocre fit: $\mathrm{CFI}>0.90$ ), the Incremental Fit Index (IFI>0.90), the Turker-Lewis Index (good fit: TL $>0.95$; mediocre fit: $0.80<\mathrm{TLI}<0.95)$, the Root Mean Square Error of Approximation (RMSEA $<0.08$ ), the Goodness of Fit Index (GFI>0.90), the Adjusted Goodness of Fit Index (AGFI>0.90) and the Standardized Root Mean Square Residual (good fit: $S R M R<0.05$; mediocre fit $S R M R<0.08$ ) (Hooper et al., 2008).

Thus, linear regression model with dummy variables was estimated for separate school groups (national and mixed curriculums), followed by a significance test for the set of dummy variables. By fitting a linear equation to the observed data, linear regression describes the connection between one dependent and more independent variables (Gordon, 2015). The linear regression could answer whether the type of curriculum affect the school performance or not.

\section{FINDINGS AND DISCUSSION}

\section{Findings}

Exploratory Factor Analysis

EFA was used to validate the instrument after experts' judgment. This research was based on the responses of 684 secondary school students who completed the 29-item questionnaire.

The Kaiser-Meyer-Olkin (KMO) value in this study is 0.825 , which indicates that the sample size is sufficient for factor analysis, and the Bartlett Chi-Square approximation is 3089.58 with $\mathrm{p}=0.000$, as in Table 3 . KMO value close to 1 means the correlation pattern is compact enough to yield different and dependable factors. Therefore, the EFA approach is found to be appropriate for use in this study, based on the findings of the Kaiser-MeyerOlkin and Bartlett sphericity tests (Auerswald \& Moshagen, 2019).

Table 3. Kaiser-Meyer-Olkin and Barlett's Sphericity Tests

\begin{tabular}{lr}
\hline $\begin{array}{l}\text { Kaiser-Meyer-Olkin Measure } \\
\text { of Sampling Adequacy }\end{array}$ & 0.825 \\
\hline Chi-Square Approx. & 3089.581 \\
Bartlett's Test of Sphericity df & 406 \\
Sig & 0.000 \\
\hline
\end{tabular}

There were eight factors with Eigenvalues $>1$ that were obtained using Parallel Analysis (Horn, 1965), one of the preferred ways to determine the number of factors. In order to presume that the measurement has good validity, the commonalities must be more than 0.30 while doing the extraction. In all items, the analyzed instrument meets this condition, as presented in Table 4.

Furthermore, the analysis of the main components revealed that the eight factors account for 49.918 percent of the overall variance. The following are the names of the eight factors: Factor 1 is Social-Emotional Learning (SEL1SEL6) which has six items, each of which has a factor loading ranging from 0.438 to 0.553 . Factor 2 is the School Participation (SPA1-SPA5) which has five items with factor loadings from 0.406-0.619. Factor 3 is the Relationship (REL1-REL3) which has three items with factor loadings from 0.488-0.687. Factor 4 is the Physical and Mental Health (PMH1-PMH3) which has three items with factor loadings from 0.4590.633 . Factor 5 is the Physical Safety (PSA1PSA3) which has three items with factor loadings from 0.439-0.705. Factor 6 is the Academic Growth (ACG1-ACG3) which has three items with factor loadings from 0.401-0.626. Factor 7 is the Emotional Safety (ESA1-ESA3) which has three items with factor loadings 0.481-0.513. Factor 8 is Discipline (DIS1-DIS3) which has three items with factor loadings 0.465-0.627. Only those items with a factor loading greater than 0.40 are shown in Table 5. 
Table 4. Communalities to Perform List Extraction

\begin{tabular}{|c|c|c|}
\hline Code & Items & Extraction \\
\hline SEL1 & In general, teachers appreciate hard work more than grades. & 0.386 \\
\hline SEL2 & I get to collaborate with other students who are different from me. & 0.471 \\
\hline SEL3 & I was guided to learn from my mistakes. & 0.521 \\
\hline SEL4 & When I have a problem, I can find someone to help. & 0.577 \\
\hline SEL5 & The adults in my school help me to stay calm in stressful situations & 0.580 \\
\hline SEL6 & I can be myself in the lesson. & 0.535 \\
\hline SPA1 & I feel my contribution during the classroom activities is valuable. & 0.449 \\
\hline SPA2 & I like to participate in school events. & 0.374 \\
\hline SPA3 & I feel welcome to join any school activities. & 0.647 \\
\hline SPA4 & The adults in my school listen to my opinions. & 0.438 \\
\hline SPA5 & My teachers involve students in creating classroom rules. & 0.579 \\
\hline REL1 & I have a good relationship with my teachers. & 0.541 \\
\hline REL2 & I have a good relationship with other students. & 0.464 \\
\hline REL3 & $\begin{array}{l}\text { I have a good relationship with the school management (e.g., principal, vice-principal } \\
\text { and admin staff). }\end{array}$ & 0.558 \\
\hline PMH1 & My school has good counselors. & 0.488 \\
\hline PMH2 & My school conducts physical exercise regularly. & 0.610 \\
\hline РMH3 & My school conducts campaigns about mental health. & 0.360 \\
\hline PSA1 & To my knowledge, there is a low rate of bullying cases in my school. & 0.510 \\
\hline PSA2 & My school regularly conducts training in dealing with earthquakes and fire. & 0.650 \\
\hline PSA3 & My school regularly conducts training in dealing with the pandemic. & 0.604 \\
\hline ACG1 & Schools (teachers and facilities) played an essential role in my academic achievement. & 0.421 \\
\hline ACG2 & My test scores improved from the start I entered until today. & 0.466 \\
\hline ACG3 & I rarely get bad grades during school exams. & 0.448 \\
\hline ESA1 & I feel safe doing activities at school. & 0.524 \\
\hline ESA2 & My school conducts campaigns about the dangers of cyber bullying regularly. & 0.600 \\
\hline ESA3 & In general, the people at my school acted politely towards me. & 0.473 \\
\hline DIS1 & Teachers share the reason behind the disciplinary approaches they use. & 0.552 \\
\hline DIS2 & School rules are fair enough for me. & 0.320 \\
\hline DIS3 & Teachers' discipline positively affects my behavior. & 0.330 \\
\hline
\end{tabular}

\section{Confirmatory Factor Analysis}

They identified eight components of the school performance Confirmatory Factor Analysis (CFA) subjected cross-validation, and multicollinearity was discovered among the factors as independent variables. Figure 1 shows the CFA diagram of school performance factors. It is represented in route diagrams with latent variables represented by circles and observable variables represented by squares. The single-headed arrows reflect the covariance between the six latent variables, whereas the two-headed arrows show the expected direction of impact (Costa et al., 2016).

Eight items were dropped because they were not valid since the estimate loading factor was less than 0.5. Their codes were SEL1, SEL2, SPA1, SPA2, SPA3, PSA2, ACG1 and DIS2. The Chi-Square of the school performance instrument was value 528.69. It is not achieved the threshold with $\mathrm{df}=349$ and $\mathrm{p}$-value $=0.00$. Nevertheless, other indices were passed at least the threshold of mediocre fit. RMSEA was 0.058 (achieved the threshold of 0.08 - good fit), GFI was 0.93 (achieved the threshold of 0.90 - mediocre fit), AGFI was 0.93 (is achieved the threshold of 0.90 - mediocre fit), CFI was 0.91 (is not achieved the threshold of 0.90 - mediocre fit), IFI was 0.92 (achieved the threshold of 0.90 - mediocre fit) and TLI was 0.89 (achieved the threshold of 0.90 - mediocre fit). These results were within acceptable limits, indicating that the EFA's eight factors had been validated.

\section{Linear Regression with Dummy Variables}

A linear regression analysis with the curriculum as a binary variable $(0=$ National Curriculum and $1=$ Mixed-Curriculum) is required to see the difference in performance between schools with a national curriculum and a mixed curriculum. The calculations with SPSS found that schools with mixed curriculum did have higher performance on average than schools with a national curriculum. However, the type of curriculum usage has minimal effect on school performance. It is showed by the R-square value that reached at 0.003 , as shown in Table 6 . Regression equation was formed with variable de- 
pendent school performance $(\mathrm{Y})$ and $\mathrm{X}$ as an independent variable binary curriculum with the national curriculum as the basis of calculation is $\mathrm{Y}=\mathrm{a}+\mathrm{bX}$, while $\mathrm{a}$ and $\mathrm{b}$ are the coefficients listed in Table 7, so the equation becomes $\mathrm{Y}=$ $3.702+(0.041 *$ curriculum $)$. For national cur- riculum $\mathrm{Y}=3.703+(0.041 * 0)$ while for mixed curriculum $\mathrm{Y}=3.703+(0.041 * 1)$. However, the result is not clearly significant because $\mathrm{p}>$ 0.05 (0.164). Thus, it could not be generalized that using a mixed curriculum can affect school performance

Table 5. Factor Loadings by EFA (Pattern Matrix of the Factors and Item)

\begin{tabular}{|c|c|c|c|c|c|c|c|c|}
\hline \multirow{2}{*}{$\begin{array}{l}\text { Item's } \\
\text { Code }\end{array}$} & \multicolumn{8}{|c|}{ Components } \\
\hline & 1 & 2 & 3 & 4 & 5 & 6 & 7 & 8 \\
\hline SEL1 & 0.441 & & & & & & & \\
\hline SEL2 & 0.438 & & & & & & & \\
\hline SEL3 & 0.553 & & & & & & & \\
\hline SEL4 & 0.489 & & & & & & & \\
\hline SEL5 & 0.424 & & & & & & & \\
\hline SEL6 & 0.530 & & & & & & & \\
\hline SPA1 & & 0.619 & & & & & & \\
\hline SPA2 & & 0.523 & & & & & & \\
\hline SPA3 & & 0.406 & & & & & & \\
\hline SPA4 & & 0.416 & & & & & & \\
\hline SPA5 & & 0.607 & & & & & & \\
\hline REL1 & & & 0.500 & & & & & \\
\hline REL2 & & & 0.488 & & & & & \\
\hline REL3 & & & 0.697 & & & & & \\
\hline PMH1 & & & & 0.633 & & & & \\
\hline PMH2 & & & & 0.489 & & & & \\
\hline PMH3 & & & & 0.459 & & & & \\
\hline PSA1 & & & & & 0.499 & & & \\
\hline PSA2 & & & & & 0.705 & & & \\
\hline PSA3 & & & & & 0.439 & & & \\
\hline ACG1 & & & & & & 0.548 & & \\
\hline ACG2 & & & & & & 0.401 & & \\
\hline ACG3 & & & & & & 0.626 & & \\
\hline ESA1 & & & & & & & 0.513 & \\
\hline ESA2 & & & & & & & 0.481 & \\
\hline ESA3 & & & & & & & 0.581 & \\
\hline DIS1 & & & & & & & & 0.627 \\
\hline DIS2 & & & & & & & & 0.465 \\
\hline DIS3 & & & & & & & & 0.519 \\
\hline
\end{tabular}

Extraction Method: Principal Component Analysis

Rotation Method: Varimax with Kaiser Normalization. Rotation converged in 27 iterations

Table 6. Model Summary

\begin{tabular}{ccccc}
\hline Model & $\mathrm{R}$ & R Square & Adjusted R Square & Std. Error of the Estimate \\
\hline 1 & $0.053^{\mathrm{a}}$ & 0.003 & 0.001 & 0.38720 \\
\hline
\end{tabular}

a. Predictors: Curriculum

Table 7. Coefficients ${ }^{\mathrm{a}}$

\begin{tabular}{|c|c|c|c|c|c|}
\hline \multirow{2}{*}{ Model } & \multicolumn{2}{|c|}{ Unstandardized Coefficients } & \multirow{2}{*}{$\begin{array}{c}\text { Standardized Coefficients } \\
\text { Beta } \\
\end{array}$} & \multirow{2}{*}{$t$} & \multirow{2}{*}{ Sig. } \\
\hline & $\mathrm{B}$ & Std. Error & & & \\
\hline (Constant) & 3.702 & 0.021 & & 179.372 & 0.000 \\
\hline Curriculum & 0.041 & 0.030 & 0.053 & 1.392 & 0.164 \\
\hline
\end{tabular}

a. Dependent Variable: Sch_Perf 


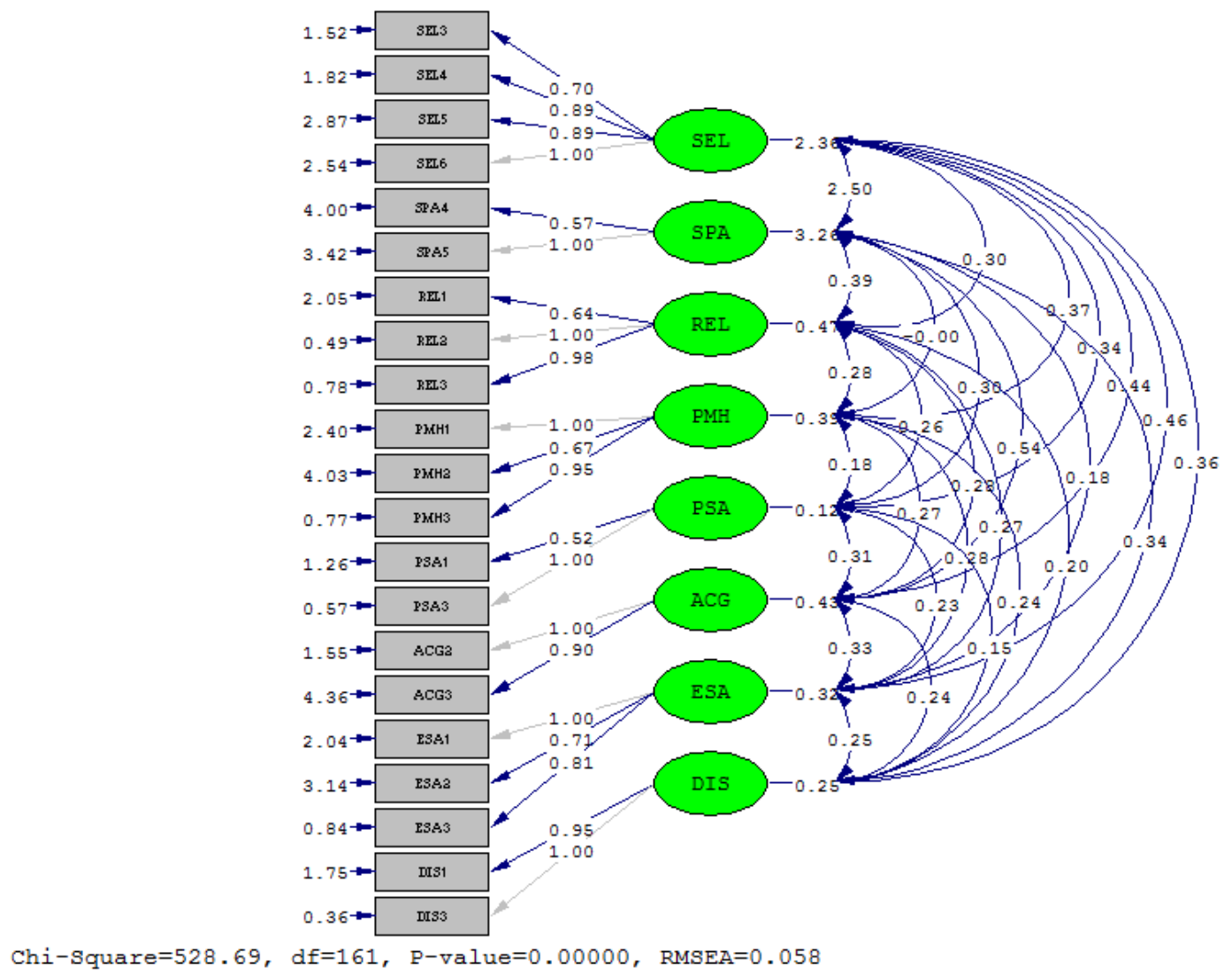

Figure 1. Confirmatory Factor Analysis Diagram

\section{Discussion}

Factors of School Performance

This study confirmed that SEL is one of the school performances factors. The finding is the meta-analysis of the 213 school-based SEL programs by Durlak et al. (2011). That analysis found that SEL program participants' social and emotional skills, attitudes, behavior, and academic achievement all increased considerably. Social and Emotional Learning (SEL) is a conceptual framework for supporting students' social, emotional, and academic competence (Edwards et al., 2019). It entails fostering social and emotional competencies through explicit instruction and student-centered learning approaches that encourage students to participate in the learning process and develop analytical, communication, as well as collaborative skills (Weissberg et al., 2015).

This finding is also in line with Dowling et al. (2019) research. They recorded significant gains in SEL intervention students' social and emotional abilities, including the reduced emotion suppression, improvements in mental health and wellbeing, and significant lower stress levels. Therefore, school-based social and emotional learning intervention aims to equip children with skills they need to deal with life's obstacles, improve their social and emotional wellbeing, accelerate their academic performance, and lower their risk of mental health problems.

The results of this study also indicate that students' participation played an essential role in their school performance. The finding has been strengthened by the result of Banatao (2011), Dogan (2015), and Pan and Zaff (2019) studies: students' level of participation in school activities can predict their academic achievement. In addition, involvement in extracurricular is connected to improvement in academic performance and school attachment (Badura et al., 2016). Although, participation of students in the educational process is not yet a standard educational practice (Cervantes \& Galván, 2019).

Schools need to transform their environment to boost student participation in class activities or events. Cervantes and Galván (2019) said that improving school environment cannot be accomplished by creating rules and regulations, or discussing topics connected to the topic, but rather through strategies for changing scholar practices and management policies. Students offered numerous opportunities to participate in their school's activities perceive their school's environment as harmonious and pleas- 
ant. The students can also feel good about themselves at school and are driven (Mithans \& Grmek, 2020).

The study results indicate that good relationships among students and adults in school also signified high performance. This finding is in line with the result of Scales et al. (2020) research. They found that students' academic motivation was substantially predicted by teachersstudent relationships at the start and end of the school year and students' sense of belonging and school climate. Moreover, the school climate may influence the success of the teaching and learning process in schools. The school climate is generated by interactions between the principal and teachers, teachers and peers, teachers and staff, teachers and students, or relationships among students (Syahril \& Hadiyanto, 2018).

Graham et al. (2016) state that relationships play a vital role in improving wellbeing in schools. Thus, the starting point for school leaders to increase student and teacher relationships is to establish a positive, open, and collaborative academic ambiance (Dorina, 2013). Moreover, the relationship between students and school staffs (non-teaching staff) has also affected students' health and wellbeing (Littlecott et al., 2018), so school management should carefully hire school staff in order to form mutually trusted relationships between faculty and students.

The findings of this study also show that physical and mental health is a part of school performance dimensions, which are in line with Pojednic et al. (2016), that school activities focused on physical and mental health could positively affect student's cognitive capacity and academic performance. Likewise, it has a positive correlation with other factors. Furthermore, poor school environmental conditions have been linked to the decline in both physical and mental health and promoting cognitive function failures (Hameen et al., 2020; Temprano et al., 2020).

School counselors can improve students' social and academic performance, but in some cases, job ambiguity and conflict limit them to acting as school administrators rather than master's-level professional educators with a mental health background (Blake, 2020). Nevertheless, good mental health services in schools could treat students and provide chances for collaboration and innovation among teachers, counselors, and psychologists (Hubbard et al., 2018). In addition, the counselors can help students to receive early detection of anxiety symptoms and access to therapy.
This study also explicitly implied that physical and emotional safety was attributed as the dimensions of school performance. This finding reinforces Kim et al. (2020) that students' school safety problems and anxiety are substantially connected with fighting, threats, and bullying, resulting in worse academic performance for both girls and boys. Nevertheless, students' safety tends to be neglected in school performance evaluation (Casey et al., 2018). For example, 42 percent of all students in a global survey of 5,805 children aged 10-12 years in both emerging and developing countries claimed they did not feel safe at school (Shean \& Mander, 2020).

School-wide bullying was found to be highly associated with emotional and physical safety in both male and female students, with physical bullying being more strongly related (Fredrick et al., 2021). Additionally, cyber bullying is a new type of bullying that has been rising over the last decade within the society, particularly in schools. It has negative social, physical, and emotional consequences for victims, offenders, and bystanders among K-12 students. Therefore, school psychologists and counselors must advocate for prevention, intervention, and more effective policies (Elbedour et al., 2020).

According to Shean and Mander (2020), emotionally unsafe surroundings are linked to stress, decreased school attendance, and worse learning engagement whereas emotionally safe conditions are linked to more positive identity development, better learning experiences, and more worthy emotions. Furthermore, feeling safe at school, connected to school, and peer support are protective variables for both mental and emotional wellbeing throughout the transition phase whereas connectivity to teachers is protective of emotional wellbeing (Lester \& Cross, 2015). Hence, it is a solid suggestion to improve emotional safety in schools to have a favorable impact on learners' academic, behavioral, emotional, physical, and mental wellbeing outcomes.

This study also shows that academic growth was one of the school performance dimensions. This finding has also been supported by a study conducted by Giersch et al. (2021) from which it can be seen that the academic growth has a more significant relationship with outcomes than either of the school performance measures. Students' scores can be compared to their previous performance rather than a benchmark, allowing for improved school perfor- 
mance scores. Policymakers can consider the progress achieved by all students and instructors, not just those who achieve competency in a particular subject, including this component in school performance measurement (Babineau, 2017).

Academic growth is a more objective than academic proficiency. Proficiency assessments track students' progress over time and are linked to their personal histories, favoring students from higher socioeconomic backgrounds. When public schools highly appreciate students with a high level of proficiency, or the number of students can reach the threshold of standardized exams, the other unfavorable schools can only receive students with lower level of proficiency (Giersch et al., 2021). Perhaps the most irritating policies that stress proficiency appear to harm students in the most underprivileged schools the most (Jennings \& Sohn, 2014; Lauen \& Gaddis, 2016). The impact of a particular school on its pupils can be better captured by judging schools based on their growth on standardized examinations (Guarino et al., 2015). As a result, researchers frequently suggest policies that prioritise measurements that indicate growth in student mastery over a school year when evaluating students (Giersch et al., 2021).

The study results indicate that controlling self-discipline is also a factor in school performance. This finding is also previously written in a research conducted by Baumann and Krskova (2016) which mentions that students with good discipline can work efficiently and leads to improved academic performance. Ehiane (2014) research demonstrated that effective school discipline should be promoted in controlling students' behavior, impacting the environment. According to Lumadi (2019) findings, a lack of disciplinary management abilities can lead to disruptive behavior, non-compliance with school rules, and low student performance.

The Effect of Curriculum Type on School Performance

The study implies that the curriculum types (national curriculum or mixed curriculum) do not affect school performance. The mixed curriculum schools, indeed, have higher performance on average, but it cannot be generalized in the population. As expected, this result does not have any solid reinforcements since lack of comparative studies between those two school types. The closest one is found by Kortelainen and Manninen (2019) that private schools out- perform public schools by a slight margin, but the difference is so minor that it is statistically insignificant. Public schools in Indonesia officially belong to national curriculum schools, but private ones have national curriculum schools and mixed curriculum schools (SPK). Thus, those findings have a low correlation.

A mixed curriculum school is a unique entity because of the restrictive Indonesian education policies (Sakhiyya, 2011). For this reason, it is very unlikely to find any previous study about mixed curriculum school. Education researchers tend to examine 'International School' as most other countries can apply only the International curriculum without mixing it with the local curriculum. Researches with 'bilingual school' as object analysis could be the most correlated study to reinforce mixed curriculum findings.

The eight factors from the established model of school performance cannot assist the comparison as well. For example, a lack of shreds of evidence that shows Social-Emotional Learning had been applied entirely in the Jakarta schools (Rahmawati, 2019). Moreover, according to a study of 452 eighth grade students under 15 in Jakarta junior high schools, the students receive insufficient social and mental health support from their schools (Triana et al., 2019). In line with a study involving 723 Senior High School students from five Jakarta administrative districts as samples, many programs have been adopted to combat bullying; however, they are ineffective at the moment (Rahmawati, 2020).

\section{CONCLUSION}

The results confirmed that socialemotional learning, school participation, relationship, physical-mental health, physicalemotional safety, academic growth, and discipline are the essential factors to improve in order to enhance school performance. A model with those validated factors could help policymakers or parents to examine the school's quality rather than using the average of standardized exams. When discussing the academic quality of an educational institution, the genuine level of a good education cannot be expressed in a single score or measured by a single factor. This study could possibly avail a chance for both policymakers and students' parents to redefine the schools accountability. Educators might embrace the more extensive and more nuanced definition of the students and school performance by strengthening the academic measurements 
and moving toward considering the nonacademic factors that help the students to succeed.

The results also confirmed that schools with mixed curricula had higher performance than schools with curriculum national, but the type of curriculums did not affect school performance. English Medium Instruction (EMI) could be the most significant contributing factor in favoring SPK (mixed curriculum) schools more than national ones. Besides, the indirect effect of students' higher socioeconomic background could significantly put SPK schools in advantage. However, if the measurement only focused on the factors controlled by the school administrators, the results stated that the difference was not significant.

\section{REFERENCES}

Andrian, D., Kartowagiran, B., \& Hadi, S. (2018). The instrument development to evaluate local curriculum in Indonesia. International Journal of Instruction, 11(4), 921-934. https://doi.org/10.12973/iji.2018.11458a

Andrietti, V., \& Su, X. (2019). Education curriculum and student achievement: Theory and evidence. Education Economics, 27(1), 4-19. https://doi.org/10.1080/09645292.2018.15 27894

Astatke, M. (2019). First-year college students' emotional intelligence and help-seeking behaviours as correlates of their academic achievement. Journal of Student Affairs in Africa, 6(2), 29-50. https://doi.org/10.24085/jsaa.v6i2.2515

Auerswald, M., \& Moshagen, M. (2019). How to determine the number of factors to retain in exploratory factor analysis: A comparison of extraction methods under realistic conditions. Psychological Methods, 24(4), 468-491. https://doi.org/10.1037/met0000200

Babineau, K. (2017). How can we measure school performance? Cowen Institute, Tulane University. https://doi.org/10.13140/RG.2.2.29676.41 605

Badura, P., Sigmund, E., Geckova, A. M., Sigmundova, D., Sirucek, J., van Dijk, J. P., \& Reijneveld, S. A. (2016). Is participation in organized leisure-time activities associated with school performance in adolescence? PLOS ONE, 11(4), e0153276.

https://doi.org/10.1371/journal.pone.0153 276

Banatao, E. J. (2011). Educational resilience: The relationship between school protective factors and student achievement. Doctoral thesis, San Diego State University, San Diego, CA.

Baumann, C., \& Krskova, H. (2016). School discipline, school uniforms and academic performance. International Journal of Educational Management, 30(6), 10031029. https://doi.org/10.1108/IJEM-092015-0118

Blake, M. K. (2020). Other duties as assigned: The ambiguous role of the high school counselor. Sociology of Education, 93(4), 315-330. https://doi.org/10.1177/003804072093256 3

Brackett, M. A. (2016). The emotion revolution: Enhancing social and emotional learning in school. National Association of Independent Schools. https://www.nais.org/magazine/independe nt-school/summer-2016/the-emotionrevolution/

Buchanan, J., Burridge, N., \& Chodkiewicz, A. (2018). Maintaining global citizenship education in schools: A challenge for Australian educators and schools. Australian Journal of Teacher Education, 43(4), 51-67. https://doi.org/10.14221/ajte.2018v43n4.4

Casey, M., Schiman, J. C., \& Wachala, M. (2018). Local violence, academic performance, and school accountability. AEA Papers and Proceedings, 108, 213216. https://doi.org/10.1257/pandp.20181109

Cervantes, A. O., \& Galván, L. P. (2019). El aprendizaje servicio, una estrategia para impulsar la participación y mejorar la convivencia escolar. Psicoperspectivas. Individuo y Sociedad, 18(1). https://doi.org/10.5027/psicoperspectivasVol18-Issue1-fulltext-1478

Costa, J., Marôco, J., Pinto-Gouveia, J., Ferreira, C., \& Castilho, P. (2016). Validation of the psychometric properties of the selfcompassion scale. Testing the factorial validity and factorial invariance of the 
measure among borderline personality disorder, anxiety disorder, eating disorder and general populations. Clinical Psychology \& Psychotherapy, 23(5), 460468. https://doi.org/10.1002/cpp.1974

Dearden, J. (2016). English as a medium of instruction - A growing global phenomenon. University of Oxford. https://doi.org/10.13140/RG.2.2.12079.94 888

Dewi, A. U. (2021). Curriculum reform in the decentralization of education in Indonesia: Effect on students' achievements. Jurnal Cakrawala Pendidikan, 40(1), 158-169. https://doi.org/10.21831/cp.v40i1.33821

Dogan, U. (2015). Student engagement, academic self-efficacy, and academic motivation as predictors of academic performance. The Anthropologist, 20(3), 553-561. https://doi.org/10.1080/09720073.2015.11 891759

Dorina, R. (2013). School climate as an important component in school effectiveness. Academicus International Scientific Journal, 8, 110-125. https://doi.org/10.7336/academicus.2013. 08.06

Dowling, K., Simpkin, A. J., \& Barry, M. M. (2019). A cluster randomized-controlled trial of the mindout social and emotional learning program for disadvantaged postprimary school students. Journal of Youth and Adolescence, 48(7), 1245-1263. https://doi.org/10.1007/s10964-01900987-3

Duckworth, A. L., \& Yeager, D. S. (2015). Measurement matters. Educational Researcher, 44(4), 237-251. https://doi.org/10.3102/0013189X155843 27

Durlak, J. A., Weissberg, R. P., Dymnicki, A. B., Taylor, R. D., \& Schellinger, K. B. (2011). The impact of enhancing students' social and emotional learning: A metaanalysis of school-based universal interventions. Child Development, 82(1), 405-432. https://doi.org/10.1111/j.14678624.2010.01564.X

Edwards, M. S., King, J. B., \& Ashkanasy, N. M. (2019). Social and emotional learning in graduate school to improve student well-being and performance: A proposed training program. New Directions for Teaching and Learning, 2019(160), 91105. https://doi.org/10.1002/t1.20367

Ehiane, O. S. (2014). Discipline and academic performance (A study of selected secondary schools in Lagos, Nigeria). International Journal of Academic Research in Progressive Education and Development, 3(1), 181-194. https://doi.org/10.6007/IJARPED/v3i $1 / 758$

Elbedour, S., Alqahtani, S., Rihan, I. E. S., Bawalsah, J. A., Booker-Ammah, B., \& Turner, J. F. (2020). Cyberbullying: Roles of school psychologists and school counselors in addressing a pervasive social justice issue. Children and Youth Services Review, 109, 104720. https://doi.org/10.1016/j.childyouth.2019. 104720

Fredrick, S. S., McClemont, A. J., Jenkins, L. N., \& Kern, M. (2021). Perceptions of emotional and physical safety among boarding students and associations with school bullying. School Psychology Review, 50(2-3), 441-453. https://doi.org/10.1080/2372966X.2021.1 873705

Galloway, N., Kriukow, J., \& Numajiri, T. (2017). Internationalisation, higher education and the growing demand for English: An investigation into the English medium of instruction (EMI) movement in China and Japan. British Council ELT Research Papers 17.02, 1-39.

George, D., \& Mallery, P. (2010). SPSS for Windows step by step: A simple guide and reference (4th ed.). Pearson Education.

Giersch, J., Bottia, M. C., Stearns, E., Mickelson, R. A., \& Moller, S. (2021). The predictive role of school performance indicators on students' college achievement. Educational Policy, 35(7), 1085-1115. https://doi.org/10.1177/089590481985782 7

Goldberg, J. M., Sklad, M., Elfrink, T. R., Schreurs, K. M. G., Bohlmeijer, E. T., \& Clarke, A. M. (2019). Effectiveness of interventions adopting a whole school approach to enhancing social and emotional development: A meta-analysis. 
European Journal of Psychology of

Education, 34(4), 755-782.

https://doi.org/10.1007/s10212-018-04069

Gordon, R. A. (2015). Dummy variables. In Regression analysis for the social sciences (pp. 237-299). Routledge. https://doi.org/10.4324/978131574878815

Graham, A., Powell, M. A., \& Truscott, J. (2016). Facilitating student well-being: Relationships do matter. Educational Research, 58(4), 366-383. https://doi.org/10.1080/00131881.2016.12 28841

Guarino, C. M., Reckase, M. D., \& Wooldridge, J. M. (2015). Can value-added measures of teacher performance be trusted? Education Finance and Policy, 10(1), 117-156. https://doi.org/10.1162/EDFP_a_00153

Hameed, S. (2020). Global citizenship education practices in Singapore and Australia: The fusion of the global eye with the national eye. International Journal of Comparative Education and Development, 22(3), 169-184. https://doi.org/10.1108/IJCED-10-20190052

Hameen, E. C., Ken-Opurum, B., \& Son, Y. J. (2020). Protocol for post occupancy evaluation in schools to improve indoor environmental quality and energy efficiency. Sustainability, 12(9), 3712. https://doi.org/10.3390/su12093712

Hayton, J. C., Allen, D. G., \& Scarpello, V. (2004). Factor retention decisions in exploratory factor analysis: A tutorial on parallel analysis. Organizational Research Methods, 7(2), 191-205. https://doi.org/10.1177/109442810426367 5

Hooper, D., Coughlan, J., \& Mullen, M. R. (2008). Evaluating model fit: A synthesis of the structural equation modelling literature. The 7th European Conference on Research Methodology for Business and Management Studies. https://arrow.tudublin.ie/cgi/viewcontent. cgi?article $=1046 \&$ context=buschmancon

Horn, J. L. (1965). A rationale and test for the number of factors in factor analysis. Psychometrika, 30(2), 179-185.
https://doi.org/10.1007/BF02289447

Hubbard, G., Woods-Giscombe, C. L., Hageman, A., \& Vimba, N. (2018). Innovative clinical training site for psychiatric mental health nurse practitioner students: Elementary schoolbased group therapy (Manuscript ID UMHN-2017-0143). Issues in Mental Health Nursing, 39(4), 357-361. https://doi.org/10.1080/01612840.2017.14 06021

Iantovics, L. B., Rotar, C., \& Morar, F. (2019). Survey on establishing the optimal number of factors in exploratory factor analysis applied to data mining. WIREs Data Mining and Knowledge Discovery, 9(2), 1-20. https://doi.org/10.1002/widm.1294

ISC Research. (2021). Why parents select an international school and the impact of COVID-19 on school choice. ISC Research White Paper. https://iscresearch.com/reports/whyparents-select-international-schools/

Jackson, J. J., Connolly, J. J., Garrison, S. M., Leveille, M. M., \& Connolly, S. L. (2015). Your friends know how long you will live: A 75-year study of peer-rated personality traits. Psychological Science, 26(3), 335-340. https://doi.org/10.1177/095679761456180 0

Jennings, J., \& Sohn, H. (2014). Measure for measure: How proficiency-based accountability systems affect inequality in academic achievement. Sociology of Education, 87(2), 125-141. https://doi.org/10.1177/003804071452578 7

Jöreskog, K. G., Olsson, U. H., \& Wallentin, F. Y. (2016). Multivariate analysis with LISREL. Springer.

Kim, Y. K., Sanders, J. E., Makubuya, T., \& Yu, M. (2020). Risk factors of academic performance: Experiences of school violence, school safety concerns, and depression by gender. Child \& Youth Care Forum, 49(5), 725-742. https://doi.org/10.1007/s10566-02009552-7

Kortelainen, M., \& Manninen, K. (2019). Effectiveness of private and public high schools: Evidence from Finland. CESifo 
Economic Studies, 65(4), 424-445.

https://doi.org/10.1093/cesifo/ifz014

Krupa, E. E., \& Confrey, J. (2017). Effects of a reform high school mathematics curriculum on student achievement: Whom does it benefit? Journal of Curriculum Studies, 49(2), 191-215. https://doi.org/10.1080/00220272.2015.10 65911

Lauen, D. L., \& Gaddis, S. M. (2016). Accountability pressure, academic standards, and educational triage. Educational Evaluation and Policy Analysis, 38(1), 127-147. https://doi.org/10.3102/016237371559857 7

Ledesma, R. D., \& Valero-Mora, P. (2007). Determining the number of factors to retain in EFA: An easy-to-use computer program for carrying out Parallel Analysis. Practical Assessment, Research, and Evaluation, 12(1), 2. https://doi.org/10.7275/wjnc-nm63

Lester, L., \& Cross, D. (2015). The relationship between school climate and mental and emotional wellbeing over the transition from primary to secondary school. Psychology of Well-Being, 5(1), 9. https://doi.org/10.1186/s13612-015-00378

Littlecott, H. J., Moore, G. F., \& Murphy, S. M. (2018). Student health and well-being in secondary schools: The role of school support staff alongside teaching staff. Pastoral Care in Education, 36(4), 297312.

https://doi.org/10.1080/02643944.2018.15 28624

López, D. (2019). Jack Schneider, beyond test scores: A better way to measure school quality, Cambridge: Harvard University Press, 2017, 326 pp. Gestión y Política Pública, 28(2), 583-588. https://doi.org/10.29265/gypp.v28i2.633

Lumadi, R. I. (2019). Taming the tide of achievement gap by managing parental role in learner discipline. South African Journal of Education, 39(Supplement 1), S1-S10. https://doi.org/10.15700/saje.v39ns1a170 7

Mayer, T., Geist, V., Pohl, V. S., Schwarz, J., \& Koinzer, T. (2020). A parental school choice misery: Middle class parents' dilemma in choosing a primary school in Berlin's multi-ethnic neighborhoods. Journal of Pedagogy, 11(1), 35-57. https://doi.org/10.2478/jped-2020-0003

Ministry of Education and Culture. (2014). Press workshop: Implementasi kurikulum 2013. Ministry of Education and Culture of the Republic of Indonesia. https://www.kemdikbud.go.id/kemdikbud /dokumen/Paparan/Paparan Mendikbud pada Workshop Pers.pdf

Mithans, M. M., \& Grmek, M. B. I. (2020). Relationships between student participation in the classroom and the classroom climate. Методички Видици, 11(11), 217-232. https://doi.org/10.19090/mv.2020.11.217232

Molla, M. K. (2018). Emotional intelligence and academic achievement motivation among college students. International Journal of Humanities and Social Science Invention (IJHSSI), 7(10), 1-6.

https://www.ijhssi.org/papers/vol7(10)/Ve rsion-1/A0710010105.pdf

Mundfrom, D. J., Shaw, D. G., \& Ke, T. L. (2005). Minimum sample size recommendations for conducting factor analyses. International Journal of Testing, 5(2), 159-168. https://doi.org/10.1207/s15327574ijt0502 -4

Muslim, A. B., Salim, H., \& Setyarini, S. (2020). Indonesian parental perspectives of international school partnerships involving millennial learners. Journal of Research in International Education, 19(2), 106-119. https://doi.org/10.1177/147524092095405 1

Pan, J., \& Zaff, J. F. (2019). The measurement structure of school engagement among youth in China: An exploratory structural equation modeling study. Journal of Psychoeducational Assessment, 37(3), 280-292. https://doi.org/10.1177/073428291773365 2

Pojednic, R., Peabody, S., Carson, S., Kennedy, M., Bevans, K., \& Phillips, E. M. (2016). The effect of before school physical activity on child development: A study 
protocol to evaluate the Build Our Kids Success (BOKS) Program. Contemporary Clinical Trials, 49, 103-108. https://doi.org/10.1016/j.cct.2016.06.009

Rahmawati, D. (2019). Supporting students' social-emotional learning in Indonesian primary schools [Master thesis, University of Jyväskylä, Jyväskylän yliopisto, Finlandia]. https://jyx.jyu.fi/handle/123456789/64613

Rahmawati, S. W. (2020). The role of the school climate to moderate an agreeableness personality trait on bullies. International Journal of Innovation, Creativity and Change, 12(5), 326-339. https://www.ijicc.net/images/vol12/iss5/1 2525_Rahmawati_2020_E_R.pdf

Rai, D., \& Khanal, Y. K. (2017). Emotional intelligence and emotional maturity and their relationship with academic achievement of college students in Sikkim. International Journal of Education and Psychological Research (IJEPR), 6(2), 1-5. https://ijepr.org/panel/assets/papers/351ij1 .pdf

Rinaldi, I., \& Saroh, Y. (2017). The rise of national plus school in Indonesia Education for parents and government. Lingua Didaktika: Jurnal Bahasa Dan Pembelajaran Bahasa, 10(2), 194-205. https://doi.org/10.24036/ld.v10i2.7322

Sakhiyya, Z. (2011). Interrogating identity: The international standard school in Indonesia. Pedagogy, Culture \& Society, 19(3), 345365.

https://doi.org/10.1080/14681366.2011.60 7841

Santos, L. M. Dos. (2019). Bilingual English education: Expectation of parents who enroll their children in bilingual primary schools. International Journal of Instruction, 12(4), 747-766. https://doi.org/10.29333/iji.2019.12448a

Saputra, W. N. E., Supriyanto, A., Astuti, B., Ayriza, Y., \& Adiputra, S. (2020). The effect of student perception of negative school climate on poor academic performance of students in Indonesia. International Journal of Learning, Teaching and Educational Research, 19(2), 279-291. https://doi.org/10.26803/ijlter.19.2.17
Scales, P. C., Van Boekel, M., Pekel, K., Syvertsen, A. K., \& Roehlkepartain, E. C. (2020). Effects of developmental relationships with teachers on middleschool students' motivation and performance. Psychology in the Schools, 57(4), 646-677. https://doi.org/10.1002/pits.22350

Schneider, J., Jacobsen, R., White, R., \& Gehlbach, H. (2017). Building a better measure of school quality. Phi Delta Kappan, 98(7), 43-48. https://doi.org/10.1177/003172171770263 1

Shean, M., \& Mander, D. (2020). Building emotional safety for students in school environments: Challenges and opportunities. In Health and Education Interdependence (pp. 225-248). Springer Singapore. https://doi.org/10.1007/978981-15-3959-6_12

Shimauchi, S. (2018). English-medium instruction in the internationalization of higher education in Japan: Rationales and issues. Educational Studies in Japan, 12, 77-90.

https://doi.org/10.7571/esjkyoiku.12.77

Sihotang, H., \& Datrix, S. (2018). Character education in schools implementing national curriculum and international baccalaureate. TERAPUTIK: Jurnal Bimbingan Dan Konseling, 1(3), 192201. https://doi.org/10.26539/1387

Syahril, S., \& Hadiyanto, H. (2018). Improving school climate for better quality educational management. Journal of Educational and Learning Studies, 1(1), 16-22. https://doi.org/10.32698/0182

Tedesco, J. C., Opertti, R., \& Amadio, M. (2014). The curriculum debate: Why it is important today. PROSPECTS, 44(4), 527-546. https://doi.org/10.1007/s11125014-9326-x

Temprano, J. P., Eichholtz, P., Willeboordse, M., \& Kok, N. (2020). Indoor environmental quality and learning outcomes: Protocol on large-scale sensor deployment in schools. BMJ Open, 10(3), 1-10. https://doi.org/10.1136/bmjopen2019-031233

Triana, R., Keliat, B. A., Wardani, I. Y., Sulistiowati, N. M. D., \& Veronika, M. A. (2019). Understanding the protective 
factors (self-esteem, family relationships, social support) and adolescents' mental health in Jakarta. Enfermería Clínica, 29, 629-633.

https://doi.org/10.1016/j.enfcli.2019.04.09 6

Weissberg, R. P., Durlak, J. A., Domitrovich, C. E., \& Gullotta, T. P. (2015). Social and emotional learning: Past, present, and future. In J. A. Durlak, C. E. Domitrovich, R. P. Weissberg, \& T. P. Gullotta (Eds.), Handbook of social and emotional learning: Research and practice (pp. 319). The Guilford Press.

West, M. R. (2016). Should non-cognitive skills be included in school accountability systems? Preliminary evidence from California's CORE districts. Brookings. https://www.brookings.edu/research/shoul d-non-cognitive-skills-be-included-inschool-accountability-systemspreliminary-evidence-from-californiascore-districts/

Williams, B., Onsman, A., \& Brown, T. (2010). Exploratory factor analysis: A five-step guide for novices. Australasian Journal of Paramedicine, 8(3), 1-13. https://doi.org/10.33151/ajp.8.3.93

Zhang, Z. (2018). English-medium instruction policies in China: Internationalisation of higher education. Journal of Multilingual and Multicultural Development, 39(6), 542-555. https://doi.org/10.1080/01434632.2017.14 04070 